\title{
Assessment of vegetation in Murchison falls national park five years after the completion of oil and gas exploration
}

\author{
Hindrah Akisiimire ${ }^{1}$, William Tinzaara ${ }^{2}$, Keneth Tumwebaze ${ }^{3}$ and Charles K.Twesigye ${ }^{1}$, \\ ${ }^{1}$ Department of Biological Sciences, Kyambogo University, P.O. Box 1, Kyambogo, Kampala, Uganda \\ ${ }^{2}$ Department of Agricultural Production, Kyambogo University, P.O. Box 1, Kyambogo, Kampala, \\ Uganda \\ ${ }^{3}$ Department of Environment Management, College of Agricultural and Environmental Sciences, \\ Makerere University, P.O. Box 7062, Kampala, Uganda
}

\section{KEYWORDS:}

Biodiversity hotspot;

Ecological restoration;

Plant species diversity;

Uganda

\begin{abstract}
Uganda discovered petroleum deposits in commercially viable quantities in 2006. Most areas such as Murchison Falls National Park (MFNP) where petroleum has been discovered overlap with wildlife and nature conservation with high biodiversity and sensitive ecosystems. This study sought to study the vegetation frequency index, relative abundance and diversity in former oil pads five years after the completion of oil and gas exploration in MFNP. We counted all observed plant species following a systematic random sampling technique using a $(1 \mathrm{mx} 1 \mathrm{~m})$ quadrat for herbs, $(5 \mathrm{mx} 5 \mathrm{~m})$ quadrat for shrubs, and $(10 \mathrm{mx} 10 \mathrm{~m})$ quadrat for trees. Data was collected using a $60 \mathrm{~m}$ line transect to record the identified plant species. The study used a total of eight quadrats per transect and the total number of transects were 32. A quadrat was placed every after $7 \mathrm{~m}$ along the line transect in and outside the oil pads. Each transect begun from the center (placard) of the oil pad going in directions of center to north, center to south, center to east, and center to west. This was carried out for purposes of replication and the same procedure was carried out for the control area. The same procedure was conducted at a frequency of wet $\left(4^{\text {th }}-30^{\text {th }}\right.$ April 2019) and dry ( $1^{\text {st }}-30^{\text {th }}$ June 2019$)$ seasons. The counted data was later transformed and analyzed using t-statistical tests and chi- square tests in SPSS version 20 software. The study recorded uniform and non-uniform plant species and the mean vegetation diversity of $1.9 \pm 0.06$ in oil pads and $1.71 \pm 0.12$ in control areas. The study identified 31 different plant species, and among these, seven plant species were recorded in oil pads, eight in control areas. The results of vegetation relative abundance and diversity between oil pads and control areas were generally similar. However, the study observed some plant species such as Desert date (Balanites aegyptiaca) in control areas that were completely absent in oil pads. Further studies focusing on edaphic assessments, soil chemical, and biological analysis to better understand the impacts of oil exploration in the protected area are recommended.
\end{abstract}

\section{INTRODUCTION}

Oil was first discovered in western Uganda in the 1870 s, but commercially viable oil was only confirmed in 2006 (Rwakakamba and Lukwago, 2013). Approximately 2.5 billion barrels of commercially viable oil of $\$ 2$ billion worth in annual revenue for twenty years (Shepherd,
*Corresponding author:

Email: twesigyeck@yahoo.com, +256 782353775
https://dx.doi.org/10.4314/eajbcs.v3i1.5S 
2013) was discovered under the Ugandan portion of the Albertine Rift in 2006. This would make Uganda the fifth largest oil producer in Africa (Vokes, 2012). The government of Uganda went ahead in the early 2000 s and licensed the exploration of oil prospects in the country. The government made agreements with oil companies which include Dominion Uganda Ltd, Tullow Oil plc, Heritage Oil and Gas Ltd and Neptune Petroleum Uganda Limited (NEMA, 2009). These companies discovered oil quantities in the Albertine Rift and along the border of Uganda and Democratic Republic of Congo (DRC). Uganda hosts a number of protected areas including the Queen Elizabeth National Park, Rwenzori Mountains National Park (both are World Heritage Sites), Kibaale, Semlikiand Murchison Falls National Parks, plus Toro-Semliki and Kabwoya wildlife reserves (USAID, 2007). Seven of the ten national parks and over 20 forest reserves are located in the Albertine Rift. The Albertine Rift provides ecosystem services such as tourism, water systems through lakes, rivers and wetlands. It also supports people by providing a source of livelihoods via forests, wetlands, minerals and fertile soils.

Global economic development and demand for energy have led to an expansion in oil and gas exploration, and oil and gas reserves in many cases overlap with protected areas and biodiversity Hot spots (Harfoot et al., 2018). For example, the Albertine Rift is a known hotspot of mammals, birds and plant species in Uganda. The wildlife law in Uganda allows exploration and extraction of oil under protected areas, provided that the impacts to the environment are minimized and where possible the natural habitat is restored after extraction. Initial drilling was promising, and it expanded from the Kabwoya Wildlife Reserve to other sites around Lake Albert including Murchison Falls National Park (MFNP). Uganda, Gabon and the Democratic Republic of the Congo are some of the African regions where oil exploration has occurred in protected areas (Coghlan, 2014; Dowhaniuk et al., 2018).

Human activities in a national park can lead to habitat loss from an increasing and expanding human population which is the greatest threat to a wide diversity of species (Brooks et al., 2002). Further causes of habitat loss can be recreation and transportation which may have an array of immediate and long-term impacts on species within wilderness parks (Trombulak and Frissell, 2000). Kityo (2011) also noted that other potential impacts due to increased human presence and traffic would include increased incidents of road kills, soil spills (an oil or fuel spill) on site which would result into an ecological disaster, destroying wildlife grazing rangelands and wildlife. Clearing of vegetation along seismic lines and pipelines can fragment habitat and alter predator-prey interactions (Borasin et al., 2002). Construction of drill pads, new roads and fences results into habitat loss and exacerbates fragmentation (UWA, 2012). Additionally, improved access to remote areas can increase poaching and the oil spills can have devastating effects on entire ecosystems (Johnson, 2007; Rwakakamba et al., 2014). Northrup and Wittemyer (2013) pointed out energy development impacts on wildlife as pollution, removal of vegetation for roads and oil pads, increased poacher access, altered animal migration and foraging habits. Oil and natural gas development poses heavy threats and dangers towards environmental conservation and the health and safety of the earth's biodiversity (Ericson, 2014). Increased road 
traffic due to mining can also threaten protected areas due to increased access to biodiverse regions (Laurance et al., 2009), causing drastic change to land cover due to large human migration into areas with low human population density (Wilkie and Carpenter, 1999; Wilkie et al., 2000; Laurance et al., 2014).

From an ecological perspective, development can cause large-scale and novel alterations to ecosystems, resulting in habitat loss and fragmentation (Leu et al., 2008; McDonald et al., 2009) that strongly impact terrestrial wildlife populations and their ecosystems. The most important and large-scale cause of habitat fragmentation is the expansion and intensification of human land use (Burgess and Sharpe, 1981). Habitat fragmentation has three major components, namely loss of the original habitat, reduction in habitat patch size, and increasing isolation of habitat patches, all of which contribute to a decline in biological diversity within the original habitat (Wilcox and Murphy, 1985).

Oil extraction has shown to put biodiversity conservation at risk, as exemplified in the Niger Delta, where oil spills and gas flaring have damaged biodiversity, destroyed mangrove forests, contaminated beaches, coated birds, endangered fish hatcheries, and disrupted food webs (Ugochukwu and Ertel 2008).Human disturbances from oil and gas activities affect wildlife at different levels. It may affect the structure, composition, and distribution of wildlife populations on a landscape level (Wassenaar, 2005; Vistnes and Nellemann, 2008). Various studies have indicated that wildlife displacement is a result of disturbance. For example, in the US state of Virginia, reclaimed coal mines had fewer salamanders
(Corrozino, 2009). In the state of Montana, elk continued to avoid a drill pad even after drilling was completed (Dyke and Klein, 1996). The state of California registered lower bird species richness and abundance four years after the restoration of flood control structures (Pattern and Rotenberry, 1998). Wyoming State in the US experienced the displacement of elks for 2 weeks during the seismic surveys (Gillin, 1989). Land-use changes and degradation of ecosystems by humans are the biggest global threats to biodiversity and ecosystem services (Foleyet al., 2005; Hooper et al., 2012).

Oil exploration and production has various phases ranging from seismic surveys, exploratory drilling which verifies the presence or absence and quantities of hydrocarbon reservoirs. This is followed by appraisal drilling whose purpose is to determine if the reservoir is economically viable for development. This is followed by development and production, and the final stage is decommissioning (Kasimbazi, 2012). In some cases, this is followed by restoring the site to environmentally sound conditions. It is achieved by implementing measures to encourage site re-vegetation and continued monitoring of the site after closure. For the case of MFNP, all drill pads and pad access roads north of the Nile were restored upon completion of appraisal drilling in early 2014 (Fuda, 2018). Restoration involved removal of all equipment and murram (a laterite soil used for building roads in East Africa) at the site, scarification of subsoil, reinstatement of topsoil and translocation of native grasses from nearby areas to the decommissioned access road and pad footprint (Total E\&P Uganda, 2013). There was no replanting of native trees or shrubs, which resulted in restored sites being more heavily dominated by grasses, compared 
to surrounding areas. Thus this study sought to assess the status of vegetation of the former oil pads post exploration stage. We were able to achieve that by studying the vegetation composition in former oil pads by comparing it with sites that are presumed to have never gone through anthropogenic disturbances.

\section{MATERIALS AND METHODS}

\section{Study Area}

Murchison Falls National Park (MFNP) is located in the northwestern region of Uganda and the study area is in the northern part of the park which is the main tourism circuit area. The study sites were located in Exploration Area 1 and they included Jobi 4 with a coordinate of 2 ${ }^{\circ} 2009.5 \mathrm{~N}, 31^{\circ} 2952.4 \mathrm{E}$ and Jobi East 7 having a coordinate of $2^{\circ} 2045.4 \mathrm{~N}$, $31^{\circ} 3226.8 \mathrm{E}$ (Figure 1). The study area consists mainly of mosaic grassland, dense borassus woodland, open borassus woodland; open woodland, wooded grassland and bush/shrub. The park's topography is rolling, reaching a maximum elevation of 1,291 $\mathrm{m}$ at
Rabongo Hill in the south east of the park, and the lowest elevation of $619 \mathrm{~m}$ at Lake Albert on the rift valley floor in the west. The park is hot with mean minimum temperature of $22^{\circ} \mathrm{C}$ and maxima of $29^{\circ} \mathrm{C}$ all year round. The eastern part of the park is wetter than the western part; Chobe to the East receives around 1,500 $\mathrm{mm}$ whilst Paraa receives about 1,100 mm per year. Murchison Falls National Park has two rainy seasons, from mid-March to mid-June, and from August to November (UWA 2001). The two exploration sites were drilled and restored by replanting of vegetation at different time periods (Table 1). Control areas were outside the selected oil pads within the same location. Restoration involved removal of all equipment and murram (a laterite soil used for building roads in East Africa) at the site, scarification of subsoil, reinstatement of topsoil and translocation of native grasses from nearby areas to the decommissioned access road and pad footprint (Total \& Uganda, 2013). There was no replanting of native trees or shrubs, which resulted in restored sites being more heavily dominated by grasses, compared to surrounding areas

Table 1: Time period of exploration and restoration of the study sites

Exploration Site

Jobi 4

Jobi East 7

\section{Drilled}

March- April 2013

July- August 2013
Restoration completed by

June 2013

May 2014. 


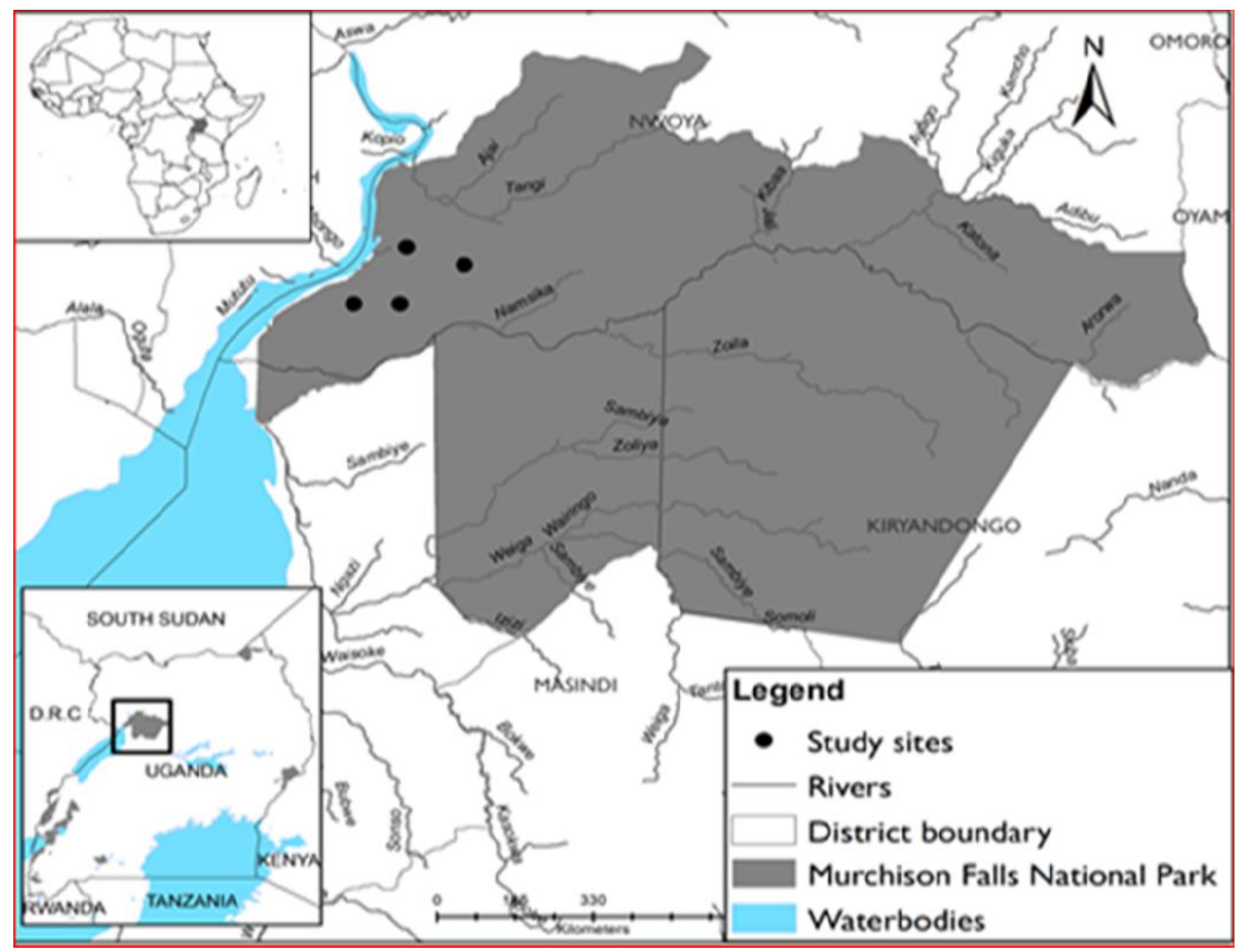

Figure 1: Location of study sites in Murchison Falls National Park in northwest Uganda

\section{Research Design}

The study used quantitative research designs which involved purposive sampling to select the exploration sites and control areas. This was on basis of easy accessibility, the cost involved in travelling, time available, and sites must be under the mandate of Uganda Wildlife Authority. The oil pad sites under the study were selected based on the fact that they must be somewhat a habitat to the mammals in the park. The control area sites were selected based on the assumption that they had the same environmental conditions as the oil pads (Jobi 4 and Jobi East 7) and had never gone through any human disturbance. The control areas were located $120 \mathrm{~m}$ away from the oil pad sites. Plant counts were replicated for both wet (April 2019) and dry (June 2019) seasons in and outside the oil pads. The study conducted replicated counts along transect lines as one of the sampling principles to ensure that variation in encounter rate (number of objects detected per unit survey effort) can be adequately estimated. All transect lines were replicated following similar randomization scheme to give all locations in the study area a known, non-zero probability of being covered by a transect (Figure 2). The 
study used a dichotomous key to identify the plants during the study. Identification of the plants was made at the sites without carrying samples to herbarium because it would be tedious. Moreover, the research permit issued to us to conduct research in a protected area does not permit carrying plant species outside the park. One of the research assistants involved during data collection was a qualified botanist experienced in plant identification, which made plant identification easy.

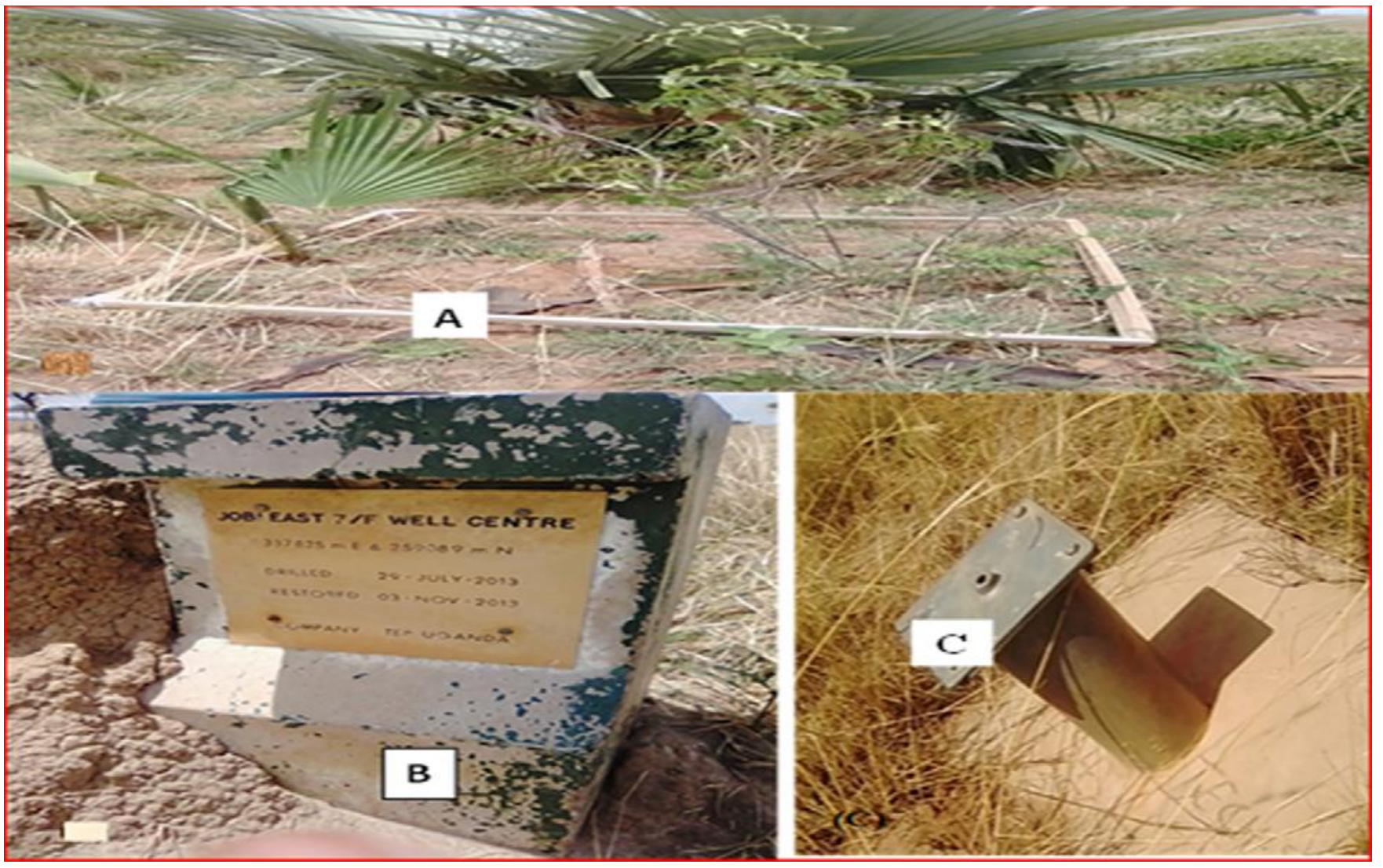

Figure 2:(A) is the $1 \times 1 \mathrm{~m}$ quadrat used to count plants along a transect, $(\mathrm{B})$ is the placard bearing the oil pad name, time of drilling and restoration, $(C)$ is the borehole that once supplied water to the oil pad camp.

\section{Data Collection}

Plant species counts were conducted in and outside the former oil pad sites using observation and recording method. A systematic random sampling technique (Greig-Smith, 1983) was followed by using a 1 x $1 \mathrm{~m}$ quadrat for herbs, $5 \times 5 \mathrm{~m}$ quadrat for shrubs, and (10x10m) quadrat for trees. Data was collected following a $60 \mathrm{~m}$ line transect to record the identified plant species. A quadrat was placed every after $7 \mathrm{~m}$ along the line transect in and outside the oil pads. In total 8 quadrats $x 4$ line transects were followed for the sites under the study. Each transect begun from the center (placard) of the oil pad going in directions of center to north, center to south, center to east, and center to west. This was carried out for the purposes of replication in order to get the true representation of each site and the same 
procedure was carried out for the control area. The same procedure was conducted at a frequency of wet $\left(4^{\text {th }}-30^{\text {th }}\right.$ April 2019) and dry $\left(1^{\text {st }}-30^{\text {th }}\right.$ June 2019$)$ seasons. It should be noted that the study intentionally measured vegetation frequency index, vegetation relative abundance and vegetation diversity but did not put in to account the relative cover of the observed plant species due to the limited time and resources that were available for the study. The study was primarily concerned with the uniformity and composition of the plant communities as a whole not the nature of plants and coverage across the sites under the study.

\section{Data Analysis}

\section{Vegetation Frequency Index}

The vegetation frequency index was determined using Equation 1. The obtained frequency indices were analyzed using Raunkier's law of frequency (1962), which is often used to study the homogeneity or uniformity of plant species in an area.

$$
F=\left\{\frac{N . o u_{i} \text { is whiı hthe spec es } o}{T \text { n.o } u \text { S }}\right\} \times 100 \ldots \ldots \text { (1) }
$$

This law of frequency assumes bimodality occurrences to describe vegetation abundance per unit area, which assumes that species are, either present or absent. In Raunkiaer's law, species are categorized in levels/classes based on frequency as: level A (0-20\%); B(21-40\%); C (41-60\%;) D (61-80\%); and E (80-100\%). The normal frequency ratio is useful in many kinds of studies in testing the uniformity of the vegetation in a given area.

Frequency levels are interpreted as $\mathrm{A}>\mathrm{B}<\mathrm{C}>\mathrm{D}<\mathrm{E}$; In general, the higher class $\mathrm{E}$ has greater homogeneity/uniformity of the vegetation. The most essential point being that class $\mathrm{E}$ should be larger than class $\mathrm{D}$ with greater number of species in class $\mathrm{E}$ than in $\mathrm{D}$. Class A means the plant species under study are very scarce, $\mathrm{B}$ means occasional presence, $\mathrm{C}$ means infrequent presence, D means frequent presence and E means abundant or very numerous presences of the plant species under the study.

\section{Vegetation Relative Abundance}

The vegetation relative abundance (RA) was determined by employing Equation 2, where A refers to the observed individual plant species.

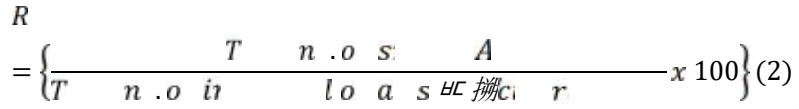

However, the study compiled mean vegetation abundance of each plant species observed to compare the mean values using t statistical tests. Mean vegetation relative abundance $(\mu)$ was computed by summing up the total number of each plant species $(\mathrm{x})$ observed divided by the total number of quadrats used in the study (Equation 3).

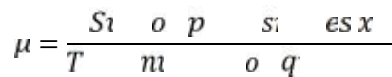

All data sorting and computing was conducted using Microsoft excel sheets before being transferred to SPSS software for further tstatistical tests.

\section{Vegetation Diversity}

Vegetation diversity was computed using Shannon Weiner diversity index $(\mathrm{H})$ that was determined by Equation (4). The corresponding 
H Max values and equitability values were calculated as well as to help make scientific conclusions of the collected data. Calculations were determined using Microsoft Word Excel 2010 before exporting it to SPSS version 20 for $\mathrm{t}$ - statistical analysis. Vegetation relative abundance and diversity between oil pads and control areas were analyzed using t statistical tests in SPSS version 20 at $\mathrm{p}=0.05$ significance level.

$$
H=\sum_{\mathrm{i}=1}^{\mathrm{s}} \mathrm{p} i \ln \mathrm{p} i
$$

In the Shannon index, $\mathrm{p}$ is the proportion $(\mathrm{n} / \mathrm{N})$; of individuals of one particular species found (n) divided by the total number of individuals found $(\mathrm{N})$, In is the natural logarism, $\Sigma$ is the sum of the calculations, and $\mathbf{s}$ is the number of species. H max values are determined when each group has the same frequency referred to as maximum diversity possible $[\log (\mathrm{x})]$.

Shannon equitability value or Evenness (E) was also determined using Equation (5).

$$
E=\frac{H}{H}
$$

Where $\mathrm{H}=$ Shannon-Weiner diversity index, $\mathrm{H}_{\max }=\ln (\mathrm{s})$ and $\mathrm{S}=$ total number of species in the sample.

\section{RESULTS}

\section{Vegetation frequency index per transect}

The frequency index analysis from the study shows that some plant species are more uniform than others (Table 2). The plant species that were observed to be uniform in both oil pads and control areas include Thatching grass (Hyparrhenia hirta), Cat's tail drop seed (Sporobolus pyramidalis), Nut grass (Cyperus rotundus) and Wandering jew (Commelina benghalensis). Plant species which are more uniform in oil pads than control areas include Garden signal grass (Urochloa panicoides), Hippo grass (Vossia cuspidate), Creeping woodsorrel (Oxalis corniculata), Star grass (Cynodon dactylon), Goats weed (Ageratum conyzoides), Devil horsewhip (Achyranthes aspera), Pickerel weed (Pontederia cantata), Tick berry (Lantana camara), Wait a bit thorn (Acacia mellifera), White thorn acacia tree (Vachellia constricta), and Candle bush (Senna alata). However, some plant species were recorded to be less uniform in oil pads than control areas and they include Feathered chloris (Chloris virgate), Bur bristled grass (Setaria verticillata), Desert date (Balanites aegyptiaca), Hoket horn (Arisonia abyssinica), Garden pink-sorrel (Oxalis latifolia), Borassus palm tree (Palmyra palm), Edible canna (Canna eduls), Guatemala (Tripsacum laxum), Sticking weed (Acacia okidetalia), Treedax daisy (Tridax procumbens), and Whistling acacia (Acacia hoki). Other recorded plant species in the study had similar uniformity in oil pads and control areas and they include Finger grass (Digitaria eriantha), Fibrous drop seed (Sporobolus stafianus), Nandi grass (Cetera ancient), Wild canny lilly flower (Canna indical), and Baboon apple (Annona glabra). 
Table 2: Frequency Index, Frequency Classes, and Vegetation Relative Abundance of the observed plant species per transect in oil pads and control areas.

\begin{tabular}{|c|c|c|c|c|c|c|c|c|}
\hline Observed Plant Species & Scientific Name & OP-FI & FC & CA-FI & FC & OP-VRA & CA-VRA & Sig. Value \\
\hline Thatching grass & Hyparrhenia hirta & 100 & $\mathrm{E}$ & 87.5 & $\mathrm{E}$ & $103.8 \pm 30.6$ & $169.6 \pm 47.8$ & $*$ \\
\hline Cat's tail drop seed & Sporobolus pyramidalis & 100 & $\mathrm{E}$ & 87.5 & $\mathrm{E}$ & $95.8 \pm 20.1$ & $148.1 \pm 41.8$ & $*$ \\
\hline Nut grass & Cyperus rotundus & 100 & $\mathrm{E}$ & 100 & $\mathrm{E}$ & $42.3 \pm 9.8$ & $95.5 \pm 20.0$ & $*$ \\
\hline Wandering jew & Commelina benghalensis & 100 & $\mathrm{E}$ & 100 & $\mathrm{E}$ & $48.6 \pm 10.2$ & $58 \pm 8.5$ & $*$ \\
\hline Feathered chloris & Chloris virgata & 12.5 & $\mathrm{~A}$ & 50 & $\mathrm{C}$ & $9.8 \pm 4.9$ & $57.5 \pm 28.1$ & $*$ \\
\hline Bur bristled grass & Setaria verticillata & 0 & A & 12.5 & A & $0 \pm 0$ & $0.75 \pm 0.74$ & $* * *$ \\
\hline Desert date & Balanites aegyptiaca & 0 & A & 37.5 & $\mathrm{~B}$ & $0 \pm 0$ & $9.8 \pm 8.9$ & $* * *$ \\
\hline Hoket horn & Arisonia abyssinica & 0 & A & 12.5 & $\mathrm{~A}$ & $0 \pm 0$ & $2.8 \pm 2.7$ & $* *$ \\
\hline Candle bush & Senna alata & 12.5 & $\mathrm{~A}$ & 0 & $\mathrm{~A}$ & $4.1 \pm 4.1$ & $0 \pm 0$ & $* * *$ \\
\hline Garden signal grass & Urochloa panicoides & 50 & $\mathrm{C}$ & 0 & A & $1.4 \pm 1.4$ & $0 \pm 0$ & $* *$ \\
\hline Hippo grass & Vossia cuspidata & 50 & $\mathrm{C}$ & 0 & $\mathrm{~A}$ & $7.8 \pm 3.1$ & $0 \pm 0$ & $* * *$ \\
\hline Creeping wood-sorrel & Oxalis corniculata & 50 & $\mathrm{C}$ & 37.5 & $\mathrm{~B}$ & $18.6 \pm 11.6$ & $14.6 \pm 8.0$ & NS \\
\hline Finger grass & Digitaria eriantha & 50 & $\mathrm{C}$ & 50 & $\mathrm{C}$ & $17.4 \pm 8.9$ & $9.8 \pm 4.0$ & NS \\
\hline Garden pink-sorrel & Oxalis latifolia & 50 & $\mathrm{C}$ & 75 & $\mathrm{D}$ & $15.3 \pm 8.4$ & $9.8 \pm 4.5$ & NS \\
\hline Star grass & Cynodon dactylon & 87.5 & $\mathrm{E}$ & 75 & $\mathrm{D}$ & $14.5 \pm 5.5$ & $13.4 \pm 4.2$ & NS \\
\hline Fibrous drop seed & Sporobolus stafianus & 25 & B & 37.5 & $\mathrm{~B}$ & $11.1 \pm 8.9$ & $14.1 \pm 10.4$ & NS \\
\hline Whitethorn acacia tree & Vachellia constricta & 37.5 & $\mathrm{~B}$ & 12.5 & $\mathrm{~A}$ & $0.9 \pm 0.4$ & $0.9 \pm 0.9$ & NS \\
\hline Baboon apple & Annona glabra & 25 & $\mathrm{~B}$ & 12.5 & A & $0.9 \pm 0.6$ & $10.6 \pm 10.6$ & NS \\
\hline Borassus palm tree & Palmyra palm & 12.5 & A & 50 & $\mathrm{C}$ & $0.3 \pm 0.2$ & $2.6 \pm 1.5$ & NS \\
\hline Goats weed & Ageratum conyzoides & 62.5 & $\mathrm{D}$ & 25 & $\mathrm{~B}$ & $8 \pm 3.7$ & $0.9 \pm 0.7$ & NS \\
\hline Nandi grass & Cetera ancient & 12.5 & A & 12.5 & A & $0.6 \pm 0.6$ & $1.5 \pm 1.5$ & NS \\
\hline Wild canny lilly flower & Canna indical & 50 & $\mathrm{C}$ & 50 & $\mathrm{C}$ & $4.6 \pm 2.1$ & $5.5 \pm 2.2$ & NS \\
\hline Devil horsewhip & Achyranthes aspera & 12.5 & A & 0 & A & $0.3 \pm 0.2$ & $0 \pm 0$ & NS \\
\hline Edible canna & Canna eduls & 0 & $\mathrm{~A}$ & 12.5 & A & $0 \pm 0$ & $0.4 \pm 0.4$ & NS \\
\hline Guatemala & Tripsacum laxum & 0 & A & 12.5 & A & $0 \pm 0$ & $0.3 \pm 0.2$ & NS \\
\hline Pickerel weed & Pontederia cantata & 12.5 & $\mathrm{~A}$ & 0 & A & $2.8 \pm 2.7$ & $0 \pm 0$ & NS \\
\hline Sticking weed & Acacia okidetalia & 0 & A & 12.5 & A & $0 \pm 0$ & $0.1 \pm 0.1$ & NS \\
\hline Tick berry & Lantana camara & 12.5 & $\mathrm{~A}$ & 0 & A & $2.9 \pm 2.9$ & $0 \pm 0$ & NS \\
\hline Treedax daisy & Tridax procumbens & 0 & $\mathrm{~A}$ & 12.5 & A & $0 \pm 0$ & $2 \pm 1.9$ & NS \\
\hline Wait a bit thorn & Acacia mellifera & 37.5 & B & 0 & A & $0.8 \pm 0.4$ & $0 \pm 0$ & NS \\
\hline Whistling acacia & Acacia hoki & 0 & A & 25 & $\mathrm{~B}$ & $0 \pm 0$ & $3 \pm 2.0$ & NS \\
\hline
\end{tabular}




\section{Vegetation relative abundance per transect}

The vegetation relative abundance in oil pads has no significant difference from the vegetation relative abundance in control areas $(\mathrm{t}=-1.946$, d.f=30, $\mathrm{p}=0.061$ ). However, the results show that there were some plant species that were significantly more abundant in control areas than in the oil pads (Table 2) which include Thatching grass (Hyparrhenia hirta), Cat's tail drop seed (Sporobolus pyramidalis), Nut grass
(Cyperus rotundus), Wandering Jew (Commelina benghalensis), Feathered chloris (Chloris virgate), Bur bristled grass (Setaria verticillata), Desert date (Balanites aegyptiaca), and Hoket horn (Arisonia abyssinica). On the other hand, some recorded plant species were more significantly abundant in oil pads than control areas and they include Candle bush (Senna alata), Garden signal grass (Urochloa panicoides), and Hippo grass (Vossia cuspidata).

Table 3: Plant species recorded per transect in oil pads and control areas

\begin{tabular}{|c|c|c|c|c|}
\hline Species Common Name & Scientific Name & Type of Plant & Oil Pads & Control Areas \\
\hline Baboon apple & Annonaglabra & Shrub & + & + \\
\hline Borassus palm tree & Palmyra palm & Tree & + & + \\
\hline Bur bristled grass & Seteriaverticullata & Grass & - & + \\
\hline Candle bush & Sennaalata & Tree & + & - \\
\hline Cat's tail drop seed & Sporoboluspyramidalis & Grass & + & + \\
\hline Creeping wood-sorrel & Oxalis corniculata & Grass & + & + \\
\hline Desert date & Balanites aegyptiaca & Shrub & - & + \\
\hline Devil horsewhip & Achyranthesaspera & Shrub & + & - \\
\hline Edible canna & Canna eduls & Shrub & - & + \\
\hline Feathered chloris & Chlorisvirgata & Grass & + & + \\
\hline Fibrous drop seed & Sporobolusstafianus & Grass & + & + \\
\hline Finger grass & Digitariaeriantha & Grass & + & + \\
\hline Garden Pink-sorrel & Oxalis latifolia & Grass & + & + \\
\hline Garden signal grass & Urochbapanicoides & Grass & + & - \\
\hline Goatsweed & Ageratum conyzoides & Grass & + & + \\
\hline Guntamala & Tribsacumlaxom & Grass & - & + \\
\hline Hippo grass & Vossiacuspidata) & Grass & + & - \\
\hline Hokes horn & Harrisoniaabyssinica & Grass & - & + \\
\hline Nandi grass & Cetera ancient & Grass & + & + \\
\hline Nut grass & Cyperusrotundus & Grass & + & + \\
\hline Pickerel weed & Pontederia cantata & Grass & + & - \\
\hline Star grass & Cynodondactylon & Grass & + & + \\
\hline Sticking weed & Acacia okidetalia & Grass & - & + \\
\hline Thatching grass & HyparrheniaHirta & Grass & + & + \\
\hline Tick berry & Lantana Camara & Grass & + & - \\
\hline Treedax daisy & Tridaxprocumbens & Grass & - & + \\
\hline Wait a bit thorn & Acacia mellifera & Shrub & + & - \\
\hline Wandering jew & Commelinabenghalensis & Grass & + & + \\
\hline Whitethorn acacia tree & Vachelliaconstricta & Tree & + & + \\
\hline Whistling acacia & Acacia hoki & Tree & - & + \\
\hline Wild canna lilly flower & Canna indical & Shrub & + & + \\
\hline \multicolumn{3}{|c|}{ Total number of plant species present } & 23 & 24 \\
\hline
\end{tabular}

$+=$ Plant species present, - = Plant species absent, OP = Oil Pads, CA = Control Areas, Total number of quadrats per transect $=8$, Total number of transects in oil pads $=16$, Total number of transects in control areas $=16$ 
The study also recorded a non-significant difference in the vegetation relative abundance of some plant species between oil pads and control areas which include Creeping woodsorrel (Oxalis corniculata), Finger grass (Digitaria eriantha), Garden Pink-sorrel (Oxalis latifolia), Star Grass (Cynodon dactylon), Fibrous drop seed (Sporobolus stafianus), Whitethorn acacia tree (Vachellia constricta), Baboon apple (Annona glabra), Borassus palm tree (Palmyra palm), Goats weed (Ageratum conyzoides), Nandi grass (Cetera ancient), Wild canny lilly flower (Canna indical), Devil horsewhip (Achyranthes aspera), Edible canna (Canna eduls), Guatemala (Tripsacum laxum), Pickerel weed (Pontederia cantata), Sticking weed (Acacia okidetalia), Tick berry (Lantana camara), Treedax daisy (Tridax procumbens), Wait a bit thorn (Acacia mellifera), and Whistling acacia (Acacia hoki).

\section{Observed plant species per transect}

A total of 16 various grass plant species, 4 shrub plant species and 3 tree species were recorded in oil pads whilst a total number of 17 grasses, 4 shrubs, and 3 trees were recorded in control areas. Some of the observed plant species were recorded in both oil pads and control areas, while others were in either of the two sites (Table 3). However, the total number of plant species recorded in oil pads were not significantly different from the ones recorded in control areas $\left(\chi^{2}=8.29\right.$, d.f $\left.=1, p>0.05\right)$.

\section{Vegetation diversity per transect}

The results of Shannon Weiner vegetation index per transect at both oil pads and control areas are presented in table 4 . The results show a relatively higher mean vegetation diversity per transect at oil pads $(1.9 \pm 0.058)$ compared to at control areas $(1.71 \pm 0.120)$. The study results show a non-significant difference in the vegetation diversity between the former oil pads and control areas $(\mathrm{t}=2.114$, d.f $=7, \mathrm{p}=0.072)$. This indicates that there are no habitat variations post oil and gas exploration. The results indicate a non-significant difference between the vegetation species equitability between oil pads and control areas $(\mathrm{t}=2.118$, d.f $=7, \mathrm{p}=0.072)$. The mean equitability of vegetation per transect in oil pads and control areas is $0.80 \pm 0.014$ and $0.75 \pm 0.029$, respectively

Table 4: Vegetation diversity at oil pads and control areas

\begin{tabular}{llllllll}
\hline OPT & H value & H $\max$ & $\boldsymbol{E}$ value & CAT & H value & H max & $\boldsymbol{E}$ value \\
\hline Jobi4 ET & 2.05 & 2.48 & 0.83 & CA1 ET & 1.83 & 2.20 & 0.83 \\
Jobi4 ST & 2.16 & 2.56 & 0.84 & CA1 ST & 2.47 & 2.71 & 0.91 \\
Jobi4 WT & 1.89 & 2.40 & 0.79 & CA1 WT & 1.42 & 1.95 & 0.73 \\
Jobi4 NT & 1.78 & 2.20 & 0.81 & CA1 NT & 1.38 & 2.08 & 0.66 \\
JE7 ST & 1.61 & 2.20 & 0.73 & CA2 ST & 1.63 & 2.30 & 0.71 \\
JE7 WT & 1.93 & 2.40 & 0.81 & CA2 WT & 1.63 & 2.20 & 0.74 \\
JE7 NT & 1.91 & 2.48 & 0.77 & CA2 NT & 1.60 & 2.40 & 0.67 \\
JE7 ET & 1.86 & 2.20 & 0.85 & CA2 ET & 1.72 & 2.20 & 0.78 \\
\hline
\end{tabular}

OPT=Oil Pad Transect, $C A T=$ Control Area Transect, JE7 = Jobi East 7, $H$ value Shannon Weiner vegetation index, $H$ max $=M a x i m u m$ species', E value $=$ Species' equitability. ET =East transect, $S T=$ South transect, $W T=$ West transect, NT $=$ North transect, CAI $=$ Control area 1, CA2 = Control area 2,Total number of quadrats per transect $=8$, Total number of transects in oil pads $=16$, Total number of transects in control areas $=16$ 


\section{DISCUSSION}

\section{Frequency Index (FI)of vegetation}

Results from the vegetation frequency index were analyzed by Raunkiaer's law of frequency (1962) recorded the uniformity or nonuniformity of plant species in the study area. Uniform vegetation signified stable community whilst non-uniformity may suggest a disturbed vegetation community. The study recorded a number of plant species which were more uniform in control areas than in oil pads. This may suggest that these plant species are more abundant in control areas than oil pads. However, it should be noted that distribution of frequencies "depends on the number of quadrats, the size of the quadrats, and on the Index of Diversity of the population." Unless all of these factors are considered, the distribution of frequencies in classes is not meaningful (Williams, 1950). Another challenge with this methodology of vegetation assessment is that the distribution of species in the frequency classes varies with the size of sample. The results are highly influenced by the composition of the total population in terms of numbers of individuals per species.

\section{Vegetation Relative Abundance}

The study recorded a non-significant difference in the vegetation relative abundance between oil pads and control areas. The findings are not in line with Lee et al. (2013) who suggested that species richness and total vegetation cover (Fiori and Zalba, 2003) may decrease in response to road construction and natural resource extraction. The results reveal that the plant communities have been able to recover from the human disturbances caused by oil exploration. This is not in line with the report by Forbes et al. (2001), which suggested that there is a general slow recovery of plant communities from human disturbances, and other physical impacts of development for decades or centuries.

Some of the recorded plant species were more abundant in control areas than former oil pads. The findings are similar to those of Simmers and Galatowitsch (2010) which suggest that, in semi-arid environments, habitats heavily disturbed by anthropogenic activities often have lower species richness compared with undisturbed areas. However, the timeline for recovery may vary by taxa and level of disturbance (Nichols and Nichols, 2003; Walker and Moral 2003). This could be an explanation why some plant species were abundant in oil pads than control areas. Encounters of more abundant plant species in former oil pads is contrary to the findings by Prinsloo et al. (2011) which suggested that oil and gas development leads to decrease in vegetation cover. The study recorded some plant species which were more abundant in former oil pads than control areas and this is similar to Larson et al. (2001), whose findings indicate that reclaimed sites tend to have a higher abundance of species. This is because reclamation introduces new plants and offers moist and humid soil water which are better conditions than reference sites. This causes the reclaimed oil pads to have greater richness and higher abundance of the introduced plants.

\section{Vegetation diversity}

The study recorded a non-significant difference in the vegetation diversity between oil pads and control areas. This is similar to Lupardus et al. 
(2020) whose findings did not detect significant differences in species richness of recovering grasslands between reference and reclaimed well pads. However, the current study findings of no significant difference were contrary to findings by Edwards et al. (2014) which noted that mining infrastructure fragments and degrades natural habitat through the creation of roads. Another study conducted by Cui et al. (2009) and Janz et al. (2019) found out that disturbances can have immediate and persistent or long lasting effects with slow recovery times on vegetation. The results are also contrary to UNEP (1997), Epstein and Selber (2002), Kumpula et al. (2011), OGP/IPIECA (2011) and Kamara et al. (2019) whose findings indicated that natural resource extraction of oil and gas exploration had well documented impacts on wildlife as well as vegetation. The fact that the vegetation diversity in oil pads is similar to that in control areas is a good indicator that the habitats for mammals has been fully restored.

\section{CONCLUSIONS}

In general, the results of the current study revealed that the vegetation at the former oil pads has been fully restored. The oil exploration has not generally changed vegetation in the protected area. The oil pads are recovering at a steady rate given there is no observable difference of the vegetation relative abundance and diversity between oil pads and control areas. Based on these findings, oil companies should always do baseline studies before any development activities are carried out. The findings can serve as a benchmark for restoration once oil activities are complete. Moreover, further research studies are recommended in the former oil pads about edaphic assessments, soil chemical, and biological properties analysis. The studies would provide information to better understand if exploration altered the quality of soil in any way and also provide better guidance for further development phases of oil and gas in the park.

\section{Acknowledgements}

The authors are grateful to Uganda Wildlife Authority (UWA) for giving us access to Murchison Falls National Park to conduct this study. We also extend our appreciation to the UWA staff in the park who made our work easier by giving us all the necessary assistance needed. We wish to acknowledge the great support of Dr. Sylivia Nalubwama and Mr. Kitimbo Herbert for the valuable guidance, technical support, generosity and direct collaboration during this study.

\section{Author Contributions}

HA, CKT and WT conceived and designed the study; HA and KT conducted the research; HA and WT analyzed the data; HA and CKT wrote the paper. All the authors (HA, CKT, WT and KT) reviewed and approved the paper for submission.

\section{References}

Borasin S., Foster S., Jobarteh K., Link N., Miranda J., Pomeranse E. and Somaia P. 2002. Oil: A life cycle analysis of its health and environmental impacts. https://www.fraw.org.uk/library/toxics/epstein_2006 .pdf.

Brooks T.M., Mittermeier R.A., Mittermeier C.G., Da Fonseca G.A., Rylands A.B., Konstant W.R. and Hilton Taylor C. 2002. Habitat loss and extinction in the hotspots of biodiversity. Conserv. Biol. 16(4): 909-923.

Burgess R.L. and Sharpe D.M. (eds.) 1981. Forest island dynamics in man dominated landscapes. SpringerVerlag, New York. 
Carrozzino A.L. 2009. Evaluating wildlife response to vegetation res toration on reclaimed mine lands in southwestern Virginia (Master's Thesis). Virginia Tech. http://scholar.lib.vt.edu/theses/available/ etd05042009-150307/.

Coghlan A. 2014. Africa's Eden faces threat of oil drillers. New Sci. 222: 12-12.

Cui B., Zhao S., Zhang K., Li S., Dong S. and Bai J. 2009. Disturbance of Dabao highway construction on plant species and soil nutrients in Longitudinal Range Gorge Region (LRGR) of Southwestern China. Environ Monit Assess 158(1-4): 545.

Dowhaniuk N., Hartter J., Ryan S.J., Palace M.W. and Congalton R.G. 2018. The impact of industrial oil development on a protected area landscape: Demographic and social change at Murchison Falls Conservation Area, Uganda. Popul. Environ. 39: 197-218.

Dyke F.V. and Klein W.C. 1996. Response of elk to installation of oil wells. J. Mammal. 77: 1028-1041.

Edwards D.P., Sloan S., Weng L., Dirks P., Sayer J. and Laurance W.F. 2014. Mining and the African Environment. Conserv. Lett. 7: 302-311.

Epstein P.R. and Selber J. 2002. Oil: A life cycle analysis of its health and environmental impacts. The Center for Health and the Global Environment. Harvard Medical School, Boston.

Ericson K. 2014. A Crude Awakening: The Relationship between Petroleum Exploration and Environmental Conservation in Western Uganda. Independent Study Project (ISP) Collection.1924.

Fiori S.M. and Zalba S.M. 2003. Potential impacts of petroleum exploration and exploitation on biodiversity in a Patagonian Nature Reserve, Argentina. Biodivers. Conserv. 12(6): 1261-1270.

Foley J.A., Defries R., Asner G.P., Barford C., Bonan G., Carpenter S.R., Chapin F.S., Coe M.T., Daily G.C., Gibbs H.K., Helkowski J.H., Holloway T., Howard E.A., Kucharik C.J., Monfreda C., Patz J.A., Prentice I.C., Ramankutty N. and Snyder P.K. 2005. Global consequences of land use. Science. 309(5734):570-74.

Forbes B.C., Ebersole J.J. and Strandberg B. 2001. Anthropogenic disturbance and patch dynamics in circumpolar arctic ecosystems. Conserv. Biol. 15(4): 954-969.

Fuda R.K., Ryan S.J., Cohen J.B., Hartter J. and Frair J.L. 2018. Assessing the impacts of oil exploration and restoration on mammals in Murchison Falls Conservation Area, Uganda. Afr. J. Ecol. 56(4): 804-817.

Gillin C.M. 1989. Response of elk to seismograph exploration in the Wyoming range, Wyoming. Unpublished Master's thesis. Laramie, WY: University of Wyoming.
Harfoot M.B., Tittensor D.P., Knight S., Arnell A.P., Blyth S., Brooks S. and Scharlemann J.P. 2018. Present and future biodiversity risks from fossil fuel exploitation. Conserv. Lett. 11(4): e12448.

Hooper D.U., Adair E.C., Cardinale B.J., Byrnes J.E., Hungate B.A., Matulich K.L. and O’Connor M.I. 2012. A global synthesis reveals biodiversity loss as a major driver of ecosystem change. Nature 486(7401): 105-108.

Janz A., Whitson I.R. and Lupardus R. 2019. Soil quality and land capability of reclaimed oil and gas well pads in southern Alberta: long-term legacy effects. Can. J. Soil Sci. 99(3): 262-276.

Johnson L. 2007. Assessing the impacts of energy developments and developing appropriate mitigation in the Uganda portion of the Albertine Rift. Wildlife Conservation Society and Uganda Wildlife Authority, Kampala, Uganda.

Kamara E.D., Nina P.M. and Ochieng L.A. 2019. Effects of Oil and Gas Exploration in Murchison Falls National Park on Wildlife Resources. Afr. J. Environ. Nat. Sci. Res. 2(2): 48-57.

Kasimbazi E.B. 2012. Environmental regulation of oil and gas exploration and production in Uganda. J. Energy Nat. Resour. Law 30(2): 185-221.

Kityo R.M. 2011. The effects of oil and gas exploration in the Albertine Rift region on biodiversity: A case of protected areas (Murchison Falls National Park) (Nature Uganda, Kampala, Uganda).

Kumpula T., Pajunen A., Kaarlejärvi E., Forbes B.C. and Stammler F. 2011. Land use and land cover change in Arctic Russia: Ecological and social implications of industrial development. Glob. Environ. Change 21(2): 550-562.

Larson D.L., Anderson P.J. and Newton W. 2001. Alien plant invasion in mixed grass prairie: effects of vegetation type and anthropogenic disturbance. Ecol Appl. 11(1): 128-141.

Laurance W.F., Clements G.R., Sloan S., O'connell C.S., Mueller N.D., Goosem M. and Van Der Ree R. 2014. A global strategy for road building. Nature, 513(7517): 229-232.

Laurance W.F., Goosem M. and Laurance S.G. 2009. Impacts of roads and linear clearings on tropical forests. Trends Ecol. Evol. 24(12): 659-669.

Lee C.B., Chun J.H., Song H.K. and Cho H.J. 2013. Altitudinal patterns of plant species richness on the Baekdudaegan Mountains, South Korea: middomain effect, area, climate, and Rapoport's rule. ER, 28(1): 67-79.

Lupardus R.C., Azeria E.T., Santala K., Aubin I. and McIntosh A.C. 2020. Uncovering traits in recovering grasslands: A functional assessment of oil and gas well pad reclamation. Ecol. Eng.: 143 (Suppl): 100016. 
McDonald-Madden E., Gordon A., Wintle B. A., Walker S., Grantham H., Carvalho S. and Possingham H. P. 2009. True conservation progress. Science, 323(5910): 43-44.

National Environment Management Authority (NEMA), 2009. Environmental Sensitivity Atlas for the Albertine Graben, www.nemaug.org/atlas/ Sensitivity_Atlas_2009_May.pdf

Nichols O. G. and Nichols F. M. 2003. Long term trends in faunal re-colonization after bauxite mining in the jarrah forest of south- western Australia. Restor Ecol. 11: 261-272.

Northrup J. M. and Wittemyer G. 2013. Characterizing the impacts of emerging energy development on wildlife, with an eye towards mitigation. Ecol Lett. 16(1): 112-125.

OGP/IPIECA/API. 2011. Petroleum Industry Guidelines for Reporting Greenhouse gas Emissions.

Patten M. A. and Rotenberry J. T. 1998. Post disturbance changes in a desert breeding bird community. J. Field Ornithol. 69(4): 614-625.

Prinsloo S., Mulondo P., Mugiru G. and Plumptre A. J. 2011. Measuring responses of wildlife to oil operations in Murchison Falls National Park. Wildlife Conservation Society and Uganda Wildlife Authority.

Rwakakamba M. and Lukwago D. 2013. Farmers in Uganda's oil economy: deal or no deal. Kampala: Agency for Transformation.

Rwakakamba M., Mpiira A. S. and Turyatemba J. 2014. Tourism in Uganda's oil economy: Deal or no Deal! Agency for Transformation.

Shepherd B. 2013. Oil in Uganda: international lessons for success. London, UK: Royal Institute of International Affairs.

Simmers S. M. and Galatowitsch S. M. 2010. Factors affecting re-vegetation of oil field access roads in semiarid grassland. Restor Ecol. 18: 27-39.

Total E. and Uganda P. 2013. Proposed appraisal drilling: Mpyo field (south area) ESIA scoping report and terms of reference. Un published report.

Trombulak S. C. and Frissell C. A. 2000. Review of ecological effects of roads on terrestrial and aquatic communities. Conserv. Biol. 14(1): 18-30.
Uganda Wildlife Authority 2001. Murchison Falls National Park, Bugungu Wildlife Reserve, Karuma Wildlife Reserve. General Management Plan (July 2001-June 2011).

Uganda Wildlife Authority 2012. General management plan for Murchison Falls National Park, Karuma Wildlife Reserve, and Bugungu Wildlife Reserve 2012-2022. Ministry of Tourism, Wildlife and Heritage, Kampala, Uganda.

Ugochukwu C.N. and Ertel J. 2008. Negative impacts of oil exploration on biodiversity management in the Niger De area of Nigeria. Impact Assess. Proj. Apprais. 26(2): 139-147.

UNEP 1997 World Atlas of Desertification. United Nations Environment Programme, London.

United States Agency for International Development (USAID), 2007. Productive Resource Investments for Managing the Environment in Western Uganda Region, 2

Vistnes I. and Nellemann C. 2008. The matter of spatial and temporal scales: A review of reindeer and caribou response to human activity. Polar Biol. 31: 399-407.

Vokes R. 2012. The politics of oil in Uganda. Afr. Aff. 111(443): 303-314.

Walker L.R. and del Moral R. 2003. Primary succession and ecosystem rehabilitation. Cambridge, UK: Cambridge University Press.

Wassenaar T.D., van Aarde R.J., Pimm S.L. and Ferreira S.M. 2005. Community convergence in disturbed subtropical dune forests. Ecology, 86: 655-666.

Wilcox B.A. and Murphy D.D. 1985. Conservation strategy: the effects of fragmentation on extinction. Am. Nat. 125(6): 879-887.

Wilkie D.S. and Carpenter J. F. 1999. Bush meat hunting in the Congo Basin: an assessment of impacts and options for mitigation Biodivers. Conserv. 8(7): $927-$ 955.

Wilkie D., Shaw E., Rotberg F., Morelli G. and Auzel P. 2000. Roads, development, and conservation in the Congo Basin. Conserv. Biol. 14(6): 1614-1622. 